\title{
Blurred (Identity) Lines: A Content Analysis of the \#deleteuber Crisis on Twitter
}

\author{
Katharine E. Miller (D) and Megan C. Kendall \\ Lamb School of Communication, Purdue University, West Lafayette, Indiana, \\ USA
}

\begin{abstract}
Social media have established a growing prevalence and influence in social change, in political movements, and as vehicles for messages related to crisis. The movement \#deleteuber demonstrated this growing trend. Using quantitative content analysis, 2,000 tweets posted on Twitter were analyzed in the 2 weeks following the incident to measure how media framing may impact organizational identity. Findings reveal that users on Twitter largely framed the crisis as political, opinionated, and episodic in nature. Additionally, users most commonly associated the crisis with the organization as a collective rather than with the CEO as an individual responsible for actions prompting the crisis, thus blurring the demarcation between personal and organizational identity in online spaces.
\end{abstract}

KEYWORDS Organizational identity; framing; crisis; online activism; social media; Twitter

In today's world of $24 / 7$, around-the-clock news and networking platforms, the act of protest has taken on a new form in the age of social media (Tucker et al., 2015). First, social media provide a platform for building protest-drawing attention to issues and allowing for their quick dissemination to a wide audience. Second, once in existence, social media sites play a role in recruiting participants to support the protest and continue to spread the word, while continually and simultaneously encouraging participation. Third, once in full swing, social media continue to spread information about the protest.

In this case study, we analyze the Uber crisis and resulting \#deleteuber protest movement on Twitter. We draw on literature from media

CONTACT Katharine E. Miller, MA•E-mail: mill2005@purdue.edu • Brian Lamb School of Communication, Purdue University, West Lafayette, IN 47907, USA

๑ 2018 by Journal of International Crisis and Risk Communication Research. All rights reserved. 
studies, organizational communication, and crisis communication to analyze how a specific protest was discussed and framed via this social media platform. Conducting a content analysis allowed us to systematically investigate the content and wordage using a specific hashtag. First, we review the topics of framing and organizational identity in news and social media discourse, organizational communication, and crisis communication, leading to the presentation of our specific hypotheses. Next, we present our methodological approach in full detail and offer findings from our data collection and analysis. This project adds to literature by exploring organizational identity from a quantitative perspective to expand on the distinction between organizations and stakeholders in online environments.

\section{Review of Literature}

The purpose of this study is to evaluate organizational identity in crisis, specifically when provoked by an individual leader, and how social media has a stake in the crisis. More specifically, whereas previous literature has primarily focused on how organizations frame and communicate crises, we chose to explore how publics and stakeholders on social media respond to and frame a specific crisis-whether communicating to the organization and its leaders specifically or voicing opinions with the hope of garnering support from others online.

\section{Theoretical Framework: Thematic and Episodic Framing} Hallahan (1999) explained that frames define or limit a "message's meaning by shaping the inferences that individuals make about the message. Frames reflect judgments made by message creators or framers" (p. 207). This is particularly relevant in online spaces, where users frame an issue or situation-positioning them in either a positive or negative light.

Within framing discourse, particularly in political research, two fundamental types of frames often used in communicating issues are thematic and episodic frames (de Vreese, Peter, \& Semetko, 2001; Gross, 2008; Iyengar, 1991). Iyengar (1990, 1991) defined thematic frames as those that "focus on political issues and events in a broader context 
and present, collective, abstract, and general evidence" (Iyengar, 1990, p. 22). Thematic frames focus on broader implications-placing an issue in general societal or political/governmental contexts (An \& Gower, 2009). In contrast, episodic frames focus on and "describe concrete events and particular cases that illuminate the issue" (Iyengar, 1990, p. 22). In other words, episodic is individualistic-focusing on specific events (An \& Gower, 2009). For example, content framed thematically would place the issue at a general level- "a societal problem requiring a societal response" (An \& Gower, 2009, p. 108). Content framed episodically, therefore, would be very specific-presenting the issue or topic as an individual problem that has an individual solution.

At the core, thematic and episodic frames deal with levels of responsibility surrounding an issue or topic of public debate and discussion. An example of prior work includes An and Gower's (2009) exploration of how news media frame crises. We analyze a particular case of crisis and protest on social media by looking at how users characterize the responsibility of this crisis at either the episodic level (i.e., CEO and/ or organization) by referring to a specific event or moment or at the thematic level by considering what broader implications of this issue may be. Overall, these two framing categories are fundamental types of political news communication, so it is fitting that we use these in our study to analyze Twitter users when discussing a politically related incident. Historically, thematic frames carry more abstract information"presenting policy problems as impersonal figures and do not provide specific 'lots' or characters at which the receivers may direct their emotional reactions" (Aaroe, 2011, p. 210). In contrast, episodic frames often include "human interest details" that put "a real face and specific face on the presentation of a political problem" (Semetko \& Valkenberg, 2000, p. 95).

As Muralidharan, Rasmussen, Patterson, and Shin (2011) noted, little research has analyzed the use of framing on social media. This study adds to literature by focusing primarily on Twitter and the ways in which the public frames a response to organizations, instead of the commonly studied reverse effect. In their study on the use of Facebook and Twitter by nonprofit and media organizations during the aftermath of a recent Haitian earthquake, Muralidharan et al. found 
that the dominant frame used by organizations when communicating crisis on both Twitter and Facebook was episodic in nature. Owing to our interest in studying the politically charged protest against the company of Uber, we place social media framing in an organizational communication context.

The Case: Uber, Trump, and the \#deleteuber Movement

On Friday, January 27, 2017, President Donald Trump signed an executive order restricting and limiting entrance by immigrants and by visa and green card holders into the United States from seven majorityIslamic countries. Following the news of the immigration ban, the New York Taxi Workers Alliance called for a strike at New York's John F. Kennedy (JFK) airport (Lutz, 2017). On January 28, Travis Kalanick, CEO of Uber-a widely popular global car-sharing service and appfaced severe criticism for his ambiguous response to the immigration ban and Uber's decision to remove surge pricing at JFK, continuing to service travelers amid the taxi strike. The hashtag \#deleteuber began trending on Twitter with a public call to delete the app, with support turning to the ride-sharing rival Lyft as an alternative (Isaac, 2017; Siddiqui, 2017; Wendling, 2017), with nearly 200,000 reported users cancelling their Uber accounts as a result (Carson, 2017). Additionally, Kalanick was tied to the Trump administration for his role as one of nearly 20 top executives to advise President Trump on an economic advisory council and for his ambiguous comments regarding the ban (Lutz, 2017).

Together, these events left Uber and Kalanick in the midst of an organizational identity crisis with media, public, and political consequences. Although Kalanick was arguably the crux of the issue, the organization Uber was also left in crisis and had to make efforts to handle the online and offline public backlash. This analysis is especially relevant given the resulting implications and response from Uber and Kalanick's decision to step down from his seat on Trump's CEO advisory board on February 2, 2017 (Issac, 2017).

\section{Organizational Communication and Social Media}

Organizational communication scholars have explored the impact of social media on the communicative landscape between corpora- 
tions and their publics. The introduction of these sites in the $1990 \mathrm{os}$ impacted "the way organizations communicate with people, the way people communicate and connect with each other, be they employees, customers, partners, competitors, adversaries, advocates, the general public, members of the media, or others" (Doorley \& Garcia, 2015, p. 129). Practically, Tucker et al. (2015) defined social media as "any web-based application that allows users to contribute content, modify content already posted by others, and share content that can be viewed by others" (para. 9). Social media platforms, particularly Twitter, have become a commonplace for organizations and the public to interact and communicate regularly online. The mission of Twitter, a microblogging site with nearly 320 million active users per month, according to its corporate website, "is to give everyone the power to create and share ideas and formation instantly, without barriers" (Twitter, n.d.). Since its inception now over a decade ago, Twitter has been a place for news, journalism, pop culture, debate, and general conversation in 140 characters or less.

As Gioia, Schultz, and Corley (200o) argued, it is during these periods of ongoing interaction, and possible tension and discrepancies between internal and external audiences and messages, when issues of organizational identity and image intersect. As an increasing part of corporate communication efforts, social media have allowed organizational leaders to connect actively with a variety of audiences (Feldner \& Berg, in press). However, with this comes the risk, as Powell (2015) noted, that "Twitter presents a double-edged sword for high profile people, from celebrities to CEOs, making them accessible to fans but also open to online attacks" (p. 6). Thus organizational communication and identity take on new meanings in these spaces.

Organizational identity in the age of social media. In their study, Feldner and Berg (in press) sought "to identify how organizational leaders' Twitter use can be understood as a representation of a company's reality." They looked specifically at the blurred demarcation between individual and organizational representation on Twitter due to the modern debate regarding individual employees, particularly leaders, engaging on social media. In our case, while Kalanick did use his own individual Twitter account to respond to the negative backlash, we specifically seek to reverse what has previously been done by Feldner 
and Berg. By taking the public perspective and analyzing their collective response on social media, we can establish what or how frames were used to represent a certain reality and image of Kalanick's actions as an organizational leader, and also of the Uber organization in this crisis.

Salient to this study is the fact that stakeholders and the general public now have direct access to engaging organizations and those in leadership positions (i.e., CEOs) in conversation. Facebook and Twitter have been invaluable tools for organizations to utilize during times of crisis or change and have revealed benefits of two-way communication (Muralidharan et al., 2011). From individual to organizational levels, "social constructions of the self... are complicated by the multiple potential audiences for any given post, as contexts of work, family, and friends co-exist and collide in many social media spaces" (Molyneux, Holton, \& Lewis, 2017, p. 1). As Molyneux et al. argued, this can be particularly challenging for individuals who may blend their personal and professional identities as they present themselves online. Thus scholars have increasingly examined these tensions.

When Travis Kalanick publicly joined President Trump's advisory committee, the news and the opinions of the public went viral. As Kalanick received backlash and hateful comments via Twitter, so did the Uber organization. Interestingly, as one individual was responsible for an individual action, the news received a societal and collective response to the larger organization as a whole. This issue relates to the question of how the organization and its individual members are merged as one online identity and how this may affect the presence of organizational identity in the digital space. Historically, organizational identity has been defined as "that which is stable, enduring, unique, and central to the organization's character" (Grandy \& Mavin, 2011, p. 767). Often without intent or awareness, organizations create a certain identity on social media.

Through this, leaders of that organization are inevitably connected to that identity-simultaneously representing and communicating for their organization through online engagement. As Grandy and Mavin (2011) noted, organizational identity is socially constructed- "created through ongoing interactions with internal and external constituents including media, government, customers, suppliers, employees, and 
management" (p. 767). Organizational communication scholars have been increasingly interested in the issue of identity/identification in the digital age, particularly when the lines existing in the physical world between employee and employer are not clearly defined in online spaces. As a result, Twitter and other social media giants have changed corporate communication. More and more, we are seeing organizations receive feedback, often transmitted via media outlets (Gioia et al., 200o).

Individuals may come to know or understand an organization based on the actions and words of its leadership. Feldner and Berg (in press) argued that particularly due to today's corporate communication environment, "the separation of CEO statement and official corporate statements is virtually impossible." Undoubtedly, the same could be said for a leader's individual discourse. This aligns with this study's purpose in understanding how publics frame specific organizational crises, particularly in their attribution of individual versus collective (i.e., organization) in their communication or posts. However, we argue that CEO actions, communicative or otherwise, not just statements, are also rarely separated from those of the organization. Thus we examine our data for use of certain pronouns, attributing a message response or direct blame to either the $\mathrm{CEO}$ as an individual or the organization as a collective, even when it is not necessarily responsible for the leader's actions.

Traditionally, how organizations respond to and present their identity following a crisis event and how that may affect or alter the public's response, interpretation, or resulting actions in regard to the issue at hand have been the primary focus of extant literature. Additionally, CEOs or those in leadership positions are often seen as the spokesperson of their represented organizations (Feldner \& Berg, in press). Therefore these users may inevitably associate the CEO and his or her organization collectively through one identity, thus presenting response or blame to the organization as a whole without distinguishing it from its leader in a crisis context.

\section{Crisis and Activist Communication on Social Media}

Activism has taken a new form in the digital age, primarily due to the constant communicative nature of social media. Smith (2005) defined 
activism as "a process by which groups of people exert pressure on organizations or other institutions to change policies, practices, or conditions" (p. 5) that are found problematic. Particularly in online spaces, publics attempt to create a perceived need for an organizational reform and strive to develop a network of support and followers of mass populations on digital platforms such as social media sites. As Heath and Palenchar (2009) argued, "internet and web capabilities have been a boon to activists as these individuals can join a movement and express support behind a computer screen or mobile device" (p. 181).

Scholarship in social movement discourse has increasingly explored how social media platforms contribute to the development and popularization of protests and crises online. Coombs and Holladay (2004) defined crises as events "for which people seek causes and make attributions" (p. 27). Recent studies (Bennett, 2003; Castells, 2012; Earl \& Kimport, 2011; Van de Donk, Loader, Nixon, \& Rucht, 2004) "have asserted that the internet can help activists diversify their engagement repertoires, move beyond previous spatial and temporal confines, and organize and coordinate participation in protest events more effectively" (Theocharis, Lowe, van Deth, \& Garcia-Albacete, 2015, p. 203). The Internet, and social networking sites specifically, have allowed for "faster and easier distribution of movement information, and [have] enabled individuals to stay in touch with more people, communities, and diverse causes" (p. 204). This has led to a shift in how crisis information is disseminated and shared across online spaces.

Twitter has been especially useful and effective in joining and initiating political conversation and distribution of information. Meraz and Papacharissi (2013) argued that this site is particularly salient for these debates, providing a platform for diverse audiences to engage. Theocharis et al. (2015) noted that Twitter also "enables crowds to create their own thematic categories through hashtags and to organize conversation around specific themes or keywords" (p. 205). Hence we see popular ideas or opinions "trending" on Twitter often around political, celebrity, or other highly publicized events. Additionally, the \#deleteuber campaign grew from just a theme or keyword to a politically charged protest on this site. And undoubtedly, users have framed this campaign in a certain light. 
On the basis of the current literature in organizational identity and crisis communication, particularly in online contexts, as well as framing in media studies, we hypothesize the following:

H1: The dominant frame by users will be political as opposed to nonpolitical.

H2: Users will frame the crisis as episodic.

H3: Users will mention the name of the organization (i.e., @Uber, \#Uber) more frequently than just the CEO.

\section{Method}

To analyze the response to this ongoing crisis in an online environment, we completed a quantitative content analysis. Tweets were gathered from Twitter via hashtag (\#) utilizing API search apps. In this case, the trending \#deleteuber hashtag movement resulted in a reported 200,000+ users deleting the Uber app within weeks and CEO Travis Kalanick leaving his position on Trump's advisory council (Isaac, 2017).

\section{Data Collection}

All data collected were accessed using means and tools that were freely available, utilizing API search applications TAGS and TwitteR, ${ }^{1}$ to collect an initial population size of 23,691 tweets. Search parameters included \#deleteuber between the dates of January 28, 2017, and February 10, 2017. These dates correspond to the enactment of the controversial immigration ban executive order signed by President Trump on Friday evening on January 27 and Uber CEO Kalanick's comments to the travel ban and Uber's surge stalling at JFK Airport on January 28. The call to \#deleteuber started trending later that day, with another spike on Thursday, February 2, when it was announced that Kalanick would be stepping down from the president's council.

To collect tweets, we created a Twitter app account to gain access to the limited API data Twitter makes freely accessible to all registered app users (Twitter Developer, n.d.). We were able to conduct specific searches for tweets incorporating the \#deleteuber hashtag, following 
similar procedures from extant research utilizing social media as data (Boyd \& Crawford, 2012; Chae, 2015; Giglietto \& Selva, 2014; Humphreys, Gill, Krishnamurthy, \& Newbury, 2013; Kim, Heo, Choi, \& Park, 2014; Wang, Callan, \& Zheng, 2015).

In the TAGS search, a total of 2,691 tweets were retrieved. TwitteR was run using RStudio, and 21,00o tweets were gathered across four search queries. All tweets were consolidated into a combined Excel document. It should be noted that API collection measures provide access to data but are limited in their capacity and lead to an inevitable loss of data. API limits are set in place for the number of tweets that can be collected as well as limiting archive access. This makes our conclusions tentative, while generalizability may be later confirmed across different crisis cases in future research.

\section{Sample}

In this content analysis, a sample size of 2,00o tweets was included and coded for analysis. Tweets were systematically gathered by hand, with every 24th tweet brought into the sample. Systematic analysis was chosen over a random sample because tweets represented text that was "regularly appearing... in repetitive or continuous events" (Krippendorff, 2013, p. 116). We felt it important that the whole data set be represented, as trends may be noticed as the crisis communication changed and adapted over time. Every 24th tweet ensured the whole tweet population was sampled (Krippendorff, 2013).

\section{Measures}

We established a codebook to best evaluate how this organizational crisis was framed. Together, we went through several revisions of the codebook, adding clarification or examples or removing unnecessary codes before landing on a final version for reliability and individual coding. Measures of subject, content of tweet, and type of frame were established to help distinguish how the crisis was being addressed and consumers were identifying with Uber as an organization.

Unit of analysis. Each individual tweet was our unit of analysis and independently evaluated for the inclusion of our set coding measures. Tweets were evaluated strictly based on content. Links and images were 
not considered or used for context in this assessment-a limitation of the study to consider for future research. All tweets also included the \#deleteuber hashtag, but this was not taken into consideration in our coding measures. In other words, additional content besides the hashtag was needed to meet our coding qualifications.

Code measures. In our sample of 2,00o tweets, 18 codes were divided into six main categories: (a) mentioning the event explicitly, (b) tweet content, (c) mentioning the CEO, (d) mentioning the organization, (e) pronouns, and (f) framing (see Table 1 for examples and code designations). Categories were developed to help organize the codes and streamline the approach in working through our codebook.

The codebook targeted organizational identity, communication on social media, and how organizations communicate throughout a crisis. Our initial code cited criteria that explicitly mentioned the incident that prompted the resulting Twitter trend \#deleteuber (Coombs \& Holladay, 2004). This was a critical coding measure that flagged the tweet as directly relating to the incident. We determined the tweets needed to make explicit references to the incident at JFK Airport, Kalanick's actions and comments relating to the immigration ban, Kalanick's removal from President Trump's advisory council, and so on. In this evaluation, the \#deleteuber hashtag was disregarded and other content was required to be listed and relevant to the crisis.

All of the following codes then required a mention of the incident. Additional codes measured the rhetorical content of the tweet itself. Again, this was taken with an explicit approach. The content of the tweet was broken down into the following categories: Uber promotion, political, narrative, competitor mention, competitor promotion, and boycott promotion. By analyzing the nature of the tweet, we were able to better understand how tweets were addressing and engaging with the trending hashtag on Twitter and resulting real-world events (Grandy \& Mavin, 2011). Mentions of the CEO and Uber as an organization were also coded outside of mentions of the hashtag.

Finally, tweets were analyzed for the use of pronouns and the framing of the content. Specifically, we looked for instances of thematic and episodic framing devices. The language of the tweet was the opportunity to measure a different approach to how individuals were connecting 
TABLE 1 Coded Variables

\begin{tabular}{|c|c|c|}
\hline Variable & Description & Example \\
\hline $\begin{array}{l}\text { Mention of } \\
\text { incident }\end{array}$ & $\begin{array}{l}\text { Explicitly mentions incident } \\
\text { (i.e., immigration ban, Uber CEO } \\
\text { response to immigration ban, } \\
\text { cancelling surge prices at JFK } \\
\text { Airport following ban, CEO leaving } \\
\text { advisory council) }\end{array}$ & $\begin{array}{l}\text { RT @TwitterMoments: Spurred by } \\
\text { the \#deleteuber backlash, Uber } \\
\text { CEO Travis Kalanick has quit Trump's } \\
\text { economic advisory board. }\end{array}$ \\
\hline $\begin{array}{l}\text { Tweet content: } \\
\text { Promotion of } \\
\text { organization } \\
\text { (Uber) }\end{array}$ & $\begin{array}{l}\text { Mentions incident, promotes } \\
\text { organization (e.g., Uber discount } \\
\text { advertisement, promotion for free } \\
\text { ride) }\end{array}$ & $\begin{array}{l}\text { \#deleteuber no matter what you } \\
\text { do Uber is still helping millions } \\
\text { passengers per second over the } \\
\text { entire world even if helping Trump }\end{array}$ \\
\hline $\begin{array}{l}\text { Tweet content: } \\
\text { Political }\end{array}$ & $\begin{array}{l}\text { Mentions incident, also mentions } \\
\text { political content (e.g., Trump } \\
\text { administration, immigration ban, } \\
\text { policy) }\end{array}$ & $\begin{array}{l}\text { RT @jimdandeo: Thanks to Trump } \\
\text { ties, \#DeleteUber campaign grows } \\
\text { on social media. }\end{array}$ \\
\hline $\begin{array}{l}\text { Tweet content: } \\
\text { Narrative }\end{array}$ & $\begin{array}{l}\text { Mentions incident as narrative/ } \\
\text { story (i.e., any story related to } \\
\text { incident and/or Uber organization, } \\
\text { e.g., driver interaction, reviews, } \\
\text { personal experience, news story) }\end{array}$ & $\begin{array}{l}\text { Uber CEO Travis Kalanick is } \\
\text { resigning from President Donald } \\
\text { Trump's economic advisory council, } \\
\text { according to the ... \#deleteuber }\end{array}$ \\
\hline $\begin{array}{l}\text { Tweet content: } \\
\text { Mention of } \\
\text { competition }\end{array}$ & $\begin{array}{l}\text { Mentions incident, also mentions } \\
\text { competition (i.e., Lyft, taxi/cab } \\
\text { company) }\end{array}$ & $\begin{array}{l}\text { \#deleteuber \#uber \#lyft } \\
\text { \#donaldtrump \#free \#lyftcode } \\
\text { \#lyftpromocode \#follow \#repost } \\
\text { \#lyftpromo \#protest \#retweet }\end{array}$ \\
\hline $\begin{array}{l}\text { Tweet content: } \\
\text { Promotion of } \\
\text { competition }\end{array}$ & $\begin{array}{l}\text { Mentions incident, also promotes } \\
\text { competition (i.e., Lyft, taxi/cab } \\
\text { company) }\end{array}$ & $\begin{array}{l}\text { Want up to } \$ 20 \text { in free ride credit } \\
\text { on @Lyft?https://t.co/KPv1ziFNb8 } \\
\text { \#powertrip \#deleteuber }\end{array}$ \\
\hline $\begin{array}{l}\text { Tweet content: } \\
\text { Boycotting } \\
\text { organization }\end{array}$ & $\begin{array}{l}\text { Mentions incident, boycotts Uber } \\
\text { organization (e.g., call to action, } \\
\text { participate in boycott) }\end{array}$ & $\begin{array}{l}\text { Sign the petition: Tell @Uber @ } \\
\text { travisk to stop collaborating with } \\
\text { Trump \#DeleteUber }\end{array}$ \\
\hline $\begin{array}{l}\text { Mention of } \\
\text { CEO }\end{array}$ & $\begin{array}{l}\text { Mentions incident, also mentions } \\
\text { CEO by name, Twitter handle, or } \\
\text { position title }\end{array}$ & $\begin{array}{l}\text { RT @TwitterMoments: Spurred } \\
\text { by the \#deleteuber backlash, } \\
\text { Uber CEO Travis Kalanick has quit } \\
\text { Trump's economic advisory board. } \\
\text { \#deleteuber }\end{array}$ \\
\hline $\begin{array}{l}\text { Mention of } \\
\text { organization }\end{array}$ & $\begin{array}{l}\text { Mentions incident, also mentions } \\
\text { organization Twitter (in addition } \\
\text { to \#deleteuber) }\end{array}$ & $\begin{array}{l}\text { Catching up on \#deleteUber. People } \\
\text { are idiots. Didn't Internet outrage } \\
\text { START Uber's habit of cancelling } \\
\text { surge pricing for important things? }\end{array}$ \\
\hline $\begin{array}{l}\text { Pronoun use: } \\
\text { He/him/she/ } \\
\text { her }\end{array}$ & $\begin{array}{l}\text { Mentions incident, pronoun of } \\
\text { his/him/she/her affiliated with } \\
\text { organization and/or CEO }\end{array}$ & $\begin{array}{l}\text { Following the \#DeleteUber } \\
\text { backlash, Travis Kalanick, Uber's } \\
\text { CEO, has said that he will step down } \\
\text { from President... }\end{array}$ \\
\hline
\end{tabular}




\begin{tabular}{|c|c|c|}
\hline Variable & Description & Example \\
\hline $\begin{array}{l}\text { Pronoun use: } \\
\text { I/me }\end{array}$ & $\begin{array}{l}\text { Mentions incident, pronoun of } / / \\
\text { me affiliated with organization } \\
\text { and/or CEO }\end{array}$ & $\begin{array}{l}\text { RT @LexieS1723: Uber CEO: I'm with } \\
\text { Trump } \\
\text { Twitter: \#DeleteUber } \\
\text { Uber CEO: naw run that back, I aint } \\
\text { even mean it like that \#deleteuber }\end{array}$ \\
\hline $\begin{array}{l}\text { Pronoun use: } \\
\text { We/us }\end{array}$ & $\begin{array}{l}\text { Mentions incident, pronoun of } \\
\text { we/us affiliated with organization } \\
\text { and/or CEO }\end{array}$ & $\begin{array}{l}\text { We at Uber are proud to stand } \\
\text { behind our CEO, don't \#deleteuber } \\
\text { continue support }\end{array}$ \\
\hline $\begin{array}{l}\text { Pronoun use: } \\
\text { They/them/ } \\
\text { their }\end{array}$ & $\begin{array}{l}\text { Mentions incident, pronoun of } \\
\text { they/them/their affiliated with } \\
\text { organization and/or CEO }\end{array}$ & $\begin{array}{l}\text { RT @sahluwal: That \#deleteuber } \\
\text { trend really woke up their CEO, too } \\
\text { bad it's too late. Activism coupled } \\
\text { with action works, march on. }\end{array}$ \\
\hline $\begin{array}{l}\text { Pronoun use: } \\
\text { You/your }\end{array}$ & $\begin{array}{l}\text { Mentions incident, pronoun } \\
\text { of you/your affiliated with } \\
\text { organization and/or CEO }\end{array}$ & $\begin{array}{l}\text { RT @DanaCJones: Too late @uber } \\
\text { Travis Kalanick - \#DeleteUber - you } \\
\text { made yet another @Lyft customer }\end{array}$ \\
\hline $\begin{array}{l}\text { Framing: } \\
\text { Thematic, } \\
\text { general }\end{array}$ & $\begin{array}{l}\text { Mentions incident, frames } \\
\text { incident as generally thematic (i.e., } \\
\text { systemic, broader context, societal } \\
\text { issue/response) }\end{array}$ & $\begin{array}{l}\text { Perception was that Uber was } \\
\text { exploiting executive order on } \\
\text { immigration \#DeleteUber @ } \\
\text { lendevanna \#crisis }\end{array}$ \\
\hline $\begin{array}{l}\text { Framing: } \\
\text { Thematic, } \\
\text { systemic }\end{array}$ & $\begin{array}{l}\text { Mentions incident, frames as } \\
\text { thematic and systemic (i.e., } \\
\text { societal, regarding immigration } \\
\text { ban, anything nonpolitical) }\end{array}$ & $\begin{array}{l}\text { RT @TEN_GOP: Muslims take over } \\
\text { Dallas/Fort Worth International } \\
\text { Airport. Great to see gender } \\
\text { equality in action! } \\
\text { \#MuslimBan \#DeleteUber \#Bat ... }\end{array}$ \\
\hline $\begin{array}{l}\text { Framing: } \\
\text { Thematic, } \\
\text { political }\end{array}$ & $\begin{array}{l}\text { Mentions incident, frames as } \\
\text { thematic and political (i.e., } \\
\text { government-oriented only, not } \\
\text { mentioning immigration ban or } \\
\text { immediate crisis) }\end{array}$ & $\begin{array}{l}\text { @Uber: Stop profiting off } \\
\text { hate. Refuse to work with @ } \\
\text { RealDonaldTrump's White House } \\
\text { \#deleteUber }\end{array}$ \\
\hline $\begin{array}{l}\text { Framing: } \\
\text { Episodic }\end{array}$ & $\begin{array}{l}\text { Mentions incident, frames } \\
\text { as episodic (i.e., specific, } \\
\text { individualistic account or } \\
\text { response to incident; news report } \\
\text { or headline) }\end{array}$ & $\begin{array}{l}\text { Amid \#DeleteUber pressure, } \\
\text { Travis Kalanick backs out of Trump } \\
\text { advisory } \\
\text { Was it because I deleted Uber - both } \\
\text { app and account - that caused } \\
\text { the CEO to leave Trump's advisory } \\
\text { committee? I think so! \#deleteuber }\end{array}$ \\
\hline
\end{tabular}


and communicating with the organization and CEO throughout the crisis and to resulting engagement with the Twitter hashtag \#deleteuber. Thematic framing was separated into political and systemic due to the political component of the crisis. We felt that intentionally delineating between the two was important in understanding different frames. Again, we hoped these different coding measures would distinguish trends that measured how the tweet content was being framed and how individuals were identifying with Kalanick or with Uber as a whole organization.

\section{Coding Procedures}

Once the finalized codebook was established and agreed upon, intercoder reliability was completed (Krippendorff, 2013). We both independently coded $10 \%(n=200)$ of the final sample $(n=2,000)$ until an acceptable level of reliability was reached using Krippendorff's alpha with a value at or above .67 for each code (see Table 2). Once intercoder reliability was reached, the remaining data set of tweets was evenly split between coders for independent coding.

To code, each tweet was initially evaluated to determine if the crisis event was explicitly mentioned (our codebook explicates what specific terms or phrases were sought). If the tweet mentioned the crisis incident, then remaining codes were applied to the tweet. Multiple codes within each category could be identified with a single tweet. If the tweet did not mention the crisis, then no remaining codes were evaluated for inclusion in our sample.

$\mathrm{H} 1$ and $\mathrm{H} 2$ rely on how crisis messages were framed on Twitter. For H1, we examined dominant messages used by users to frame the crisis. Further breakdown in the content of these explicitly crisis-oriented tweets helped orient how users were framing both the crisis event and Uber's position toward the crisis event. For $\mathrm{H} 2$, we examined how framing was used when responding to the crisis on Twitter. H1 demonstrated dominant political and narrative/opinion messages, while this explores how these messages were being framed and shared. Specifically, we differentiated between thematic and episodic approaches.

$\mathrm{H} 3$ anticipated how users affiliated with the crisis: with Kalanick as CEO or with Uber as an organization. Kalanick's individual actions in 
TABLE 2 Intercoder Reliability Measures

\begin{tabular}{lc}
\multicolumn{1}{c}{ Coding variable } & Krippendorff's alpha ${ }^{\mathrm{a}}$ \\
\hline Mention of incident & .85 \\
Tweet content: Promotion of organization & 1 \\
Tweet content: Political & .87 \\
Tweet content: Narrative & .77 \\
Tweet content: Mention of competition & .67 \\
Tweet content: Promotion of competition & 1 \\
Tweet content: Boycotting organization & .69 \\
Mention of CEO & .95 \\
Mention of organization & .71 \\
Pronoun use: He/him/she/her & 1 \\
Pronoun use: I/me & .67 \\
Pronoun use: We/us & .85 \\
Pronoun use: They/them/their & .70 \\
Pronoun use: You/your & .87 \\
Framing: Thematic, general & .80 \\
Framing: Thematic, systemic & 1 \\
Framing: Thematic, political & .72 \\
\hline Framing: Episodic & .70 \\
\hline
\end{tabular}

${ }^{\mathrm{a}} \mathrm{a}=$ minimum of .67.

response to a political action prompted \#deleteuber to trend; however, Uber as an organization became a part of the conversation.

\section{Results}

For the purposes of this research, we wanted to see how the crisis event itself was being discussed in relation to Uber as an organization. Four hundred and forty-three (22.2\%) coded tweets explicitly mentioned the specific actions (i.e., JFK Airport, immigration ban, etc.) that led to the 
TABLE 3 Tweet Frequency Table

\begin{tabular}{|c|c|c|c|c|}
\hline $\begin{array}{l}\text { Coding } \\
\text { category }\end{array}$ & Code & Frequency & $\begin{array}{c}\text { All tweets } \\
\text { (\%) }\end{array}$ & $\begin{array}{c}\text { EventMention } \\
(\%)\end{array}$ \\
\hline Event & EventMention & 443 & 22.2 & 100 \\
\hline \multirow[t]{6}{*}{ Tweet content } & Political & 390 & 19.5 & 88 \\
\hline & NarrativeOpinion & 313 & 15.7 & 70.7 \\
\hline & BoycottPromotion & 64 & 3.2 & 14.4 \\
\hline & CompetitionMention & 38 & 1.9 & 8.6 \\
\hline & CompetitionPromotion & 12 & 0.6 & 2.7 \\
\hline & OrgPromotion & 3 & 0.2 & 0.6 \\
\hline \multirow[t]{4}{*}{ Framing } & EpisodicFrame & 322 & 16.1 & 72.7 \\
\hline & ThematicFrame & 120 & 6 & 33.2 \\
\hline & Political Thematic & 67 & 3.4 & 15.1 \\
\hline & SystemicThematic & 65 & 3.3 & 14.7 \\
\hline Organization & OrganizationMention & 284 & 14.2 & 64.1 \\
\hline CEO & CEOMention & 276 & 13.8 & 62.3 \\
\hline \multirow[t]{5}{*}{ Pronouns } & Ime & 30 & 1.5 & 6.8 \\
\hline & You & 22 & 1.1 & 5 \\
\hline & HeShe & 15 & 0.8 & 3.4 \\
\hline & WeUs & 7 & 0.4 & 1.6 \\
\hline & They & 6 & 0.3 & 1.4 \\
\hline
\end{tabular}

trending hashtag topic as the EventMention code. Table 3 shows values ordered in coding categories from most to least frequent occurrences.

To further examine how users on Twitter were attributing CEO or organization to the crisis, we ran a binominal logistic regression to measure the probability of factor occurrence and how variables influenced one another. We ran two regression tests to determine the effects of the crisis event against the inclusion of Uber as an organization versus the inclusion of the CEO with our total sample of tweets. Different variable factors influenced the probability of a mention of the organization or the $\mathrm{CEO}$ and thus contributed to the framing of Uber or Kalanick with 
TABLE 4 CEO + Organization Logistic Regressions

\begin{tabular}{|c|c|c|c|c|}
\hline $\begin{array}{l}\text { Binominal logistic } \\
\text { regression }\end{array}$ & Code & $\begin{array}{l}\text { Wald chi } \\
\text { square }\end{array}$ & $d f$ & Significance \\
\hline \multirow[t]{6}{*}{ CEO } & EventMention & 0.000 & 1 & 0.984 \\
\hline & Political & 0.000 & 1 & 0.999 \\
\hline & NarrativeOpinion & 0.563 & 1 & 0.453 \\
\hline & Organization & 81.309 & 1 & 0.000 \\
\hline & EpisodicFrame & 5.619 & 1 & 0.018 \\
\hline & Constant & 0.000 & 1 & 0.983 \\
\hline CEO goodness fit & Chi square & $R^{2}$ & $d f$ & Significance \\
\hline Model chi square & $1,132.474$ & & 5 & 0.000 \\
\hline Cox and Snell $R^{2}$ & & 0.433 & & \\
\hline Hosmer and Lemeshow & 0.074 & & 2 & 0.964 \\
\hline \multirow[t]{7}{*}{ Organization } & Code & $\begin{array}{l}\text { Wald chi } \\
\text { square }\end{array}$ & $d f$ & Significance \\
\hline & EventMention & 38.006 & 1 & 0.000 \\
\hline & Political & 0.000 & 1 & 0.999 \\
\hline & NarrativeOpinion & 3.198 & 1 & 0.074 \\
\hline & CEO & 81.193 & 1 & 0.000 \\
\hline & EpisodicFrame & 15.596 & 1 & 0.000 \\
\hline & Constant & 252.693 & 1 & 0.000 \\
\hline ORG goodness fit & Chi square & $R^{2}$ & $d f$ & Significance \\
\hline Model chi square & $1,049.818$ & & 5 & 0.000 \\
\hline Cox and Snell $R^{2}$ & & 0.409 & & \\
\hline Hosmer and Lemeshow & 0.715 & & 1 & 0.398 \\
\hline
\end{tabular}

Trump's immigration ban. Variables tested in the model were chosen based on their frequency counts in the content analysis. Codes that emerged with a frequency above $60 \%$ were evaluated in a regression test, including the EventMention, Political, NarrativeOpinion, EpisodicFrame, OrganizationMention, and CEOMention codes. 
Our first logistic regression tested event mention, political, narrative/opinion, mention of organization, and episodic framing on the likelihood that the CEO would also be mentioned in relation to the crisis event. The model showed statistical significance, $\chi^{2}=1,132.474$, $p<.005$, thereby rejecting the null hypothesis. The model correctly classified $94.8 \%$ of cases regarding the CEO. Notice in Table 4 that independent variables of organization (Uber) and episodic framing showed significance in this model, tentatively showing that attribution toward the $\mathrm{CEO}$ and the organization is not separated but in fact that both identities are connected to the crisis.

In our second regression, we flipped identities and tested event mention, political, narrative/opinion, mention of CEO, and episodic framing on the likelihood that the organization would also be mentioned in relation to the crisis event. The model also showed statistical significance, $\chi^{2}=1,049.818, p<.005$, thereby rejecting the null hypothesis. The model correctly classified $94.3 \%$ of cases. We find further support for $\mathrm{H} 3$ here as Uber the organization showed significance with the following variables, as noted in Table 4: event mention, CEO, and episodic.

In considering our hypotheses, the models demonstrate some interesting trends. In both tests, $\mathrm{CEO}$ and organization were connected in $89.2 \%$, or the majority, of the tweets. When considering content, however, the CEO had a lower probability of being connected to politically oriented tweets than the organization, while content regarding narrative/opinions was more evenly distributed. Finally, in the CEO test, episodic framing saw a higher correlation when connected with narrative/opinion content versus political content. Uber as an organization saw the direct opposite trend, where there was a higher probability of being connected with political content versus narrative/opinion content.

\section{Discussion and Conclusion}

In regard to our hypotheses, we explored how organizations are identified by users in a social media-driven crisis. Our findings point to several theoretical and practical implications. Confirming $\mathrm{H} 1$ and 
$\mathrm{H} 2$, users framed the crisis as episodic and individualistic in terms of personal opinions and/or experience. Additionally, when mentioning the incident of the crisis at hand, tweets were framed as political $(n=390)$ as opposed to nonpolitical. Because the Uber crisis surrounding Kalanick was politically charged, this is unsurprising. Simply looking at the frequencies presented some anticipated trends: Political connections exist in organizational crisis, and organizations have difficulty separating the brand from a crisis event. Uber is not a political entity; however, the actions of its $\mathrm{CEO}$ politicized its corporate identity, which is reflected in how users responded to the crisis.

Additionally, owing to limited space in Twitter's message platform and highly personalized nature, responses framed as episodic were unsurprising. Similarly, episodic frames are purposeful in putting a face on the presentation of a problem, most often political in nature, while in contrast, thematic frames do not attribute messages to individuals or specific events (Semetko \& Valkenberg, 200o). Therefore episodic frames were most evident $(n=133)$ in framing the crisis as an individual problem and opinionated in communicating particular cases that illuminate the issue at hand (Iyengar, 1990). Comparably, tweet content surrounding the crisis was presented as narrative or opinion $(n=313)$-highlighting again the individual and specific nature of episodic frames. Thus $\mathrm{H} 1$ and $\mathrm{H} 2$ are supported.

Additionally, this study sought to understand how Twitter users communicated and responded to the Uber crisis online by presenting a certain image or identity of the organization, which we found to be political in how it was framed and portrayed online. As presented in the literature review, while CEO Kalanick received backlash on Twitter for his personal involvement on Trump's advisory board, the Uber organization did as well. Our goal with this work was also to see if users attributed an individually caused crisis to the collective, as this attribution between the two in online spaces is often blurred. Specifically, $\mathrm{H} 3$ asked how these individuals respond to the crisis by mentioning either the CEO or organization. As expected, our results confirm that users most often included the name of the Uber organization $(n=284)$. Therefore $\mathrm{H} 3$ is supported.

Interestingly, Kalanick was most often mentioned along with Uber. 
In other words, the CEO was most often connected to the organization-mentioned together in the same tweet. In contrast, the organization was not connected to the $\mathrm{CEO}$ as frequently. So again, while the crisis may be the leader's personal responsibility due to an individual act, response and attribution were given to the organization as a whole. Rare was it that Kalanick was mentioned alone, without some comment to or about the Uber organization, even though direct access to individuals on a site such as Twitter is available to users. In terms of theory, we see this blend of personal and organizational identities as the individual was most often mentioned with the company simultaneously, while this was not the case in reverse instances. Therefore, from a pragmatic standpoint, as organizations have little to no control over the particular image and messages constructed online (Feldner \& Berg, in press), the framing and attribution of crisis to either an individual leader or a collective he or she represents are also uncontrollable. Thus, in online contexts, the two are virtually impossible to separate.

This study takes an important step in examining online activism and communication by publics in response to organizational crisis, exerting pressure and advocating for change by an institution. We know that digital platforms, such as social media, change the nature of activism by allowing the masses to join in a movement through the touch of a button (Heath \& Palenchar, 2009). This work encourages a conversation surrounding how trends on these sites, particularly Twitter, turn into an emotionally charged and change-seeking crusade. In the case of the \#deleteuber protest, one individual act, while rather political and controversial, resulted in the boycotting and extreme criticizing of a multibillion-dollar international organization. This content analysis demonstrates that organizations must recognize the role of social media in times of crisis, particularly in how publics communicate, react to, and frame such events, as well as the larger implications for postcrisis recovery and identity. From a broader and more global standpoint, this study acknowledges the potential consequences of organizations engaging on social media and the public response to those particularly connected to political bodies or individuals. Uber is an international company, operating in more than 70 countries (Uber, 2018), and while having a connection to President Trump was situated in an American 
context, the implications expanded far beyond the United States, as the Twitter and Uber communities are also global ones. Thus this case study was an attempt to show how Twitter as a social media platform could magnify a crisis and impact organizational identity in an online context.

We acknowledge several limitations of this study. First, there were few to no tweets analyzed from organizational members (e.g., Uber employees, internal stakeholders), Kalanick himself, or those users in a population that may support the Uber organization and/or CEO regardless of the political ties or response to the taxi strike at JFK. Therefore a few of our codes centered on pronoun use (i.e., I/me, you/us) were rare and thus not expanded on in data analyses. Second, our logistical model, though statistically significant, could be improved. In both cases, not all variables were individually significant, and so our conclusions and noted trends are made cautiously. The model may benefit from an increased sample size or further manipulation of variables.

Third, our analysis was limited in terms of timeline. We collected tweets approximately 2 weeks from the time of the incident and its publicity. Future research could consider a longer span of time to allow for analyzing how certain frames change or evolve over time. Finally, our method of tweet gathering should be noted as a limitation. We utilized Twitter's API services that are freely available and as such sustained an inevitable loss of data due to the sheer size and scope of trending tweets.

In summary, Kalanick's and Uber's actions and response prompted a reaction on Twitter that called for the protest action of \#deleteuber. Social media perpetuate much noise, content, and reactionary responses; however, with a trending topic targeting an organization, such as the situation Uber faced with Trump's immigration ban, it is important to understand how these messages are framed and discussed. This study provides support for current literature on framing and organizational identity but moves it to an online context. Social media activism is a fast-growing phenomenon that has both societal and political implications that are affecting organizations as identity lines become blurred and social media exert the power to prompt change. 
Katharine E. Miller, MA, is a doctoral student and graduate assistant at Purdue University studying organizational communication, corporate social responsibility (CSR), and research methods. Her research focuses on CSR from an internal perspective, organizational identity, and rhetorical approaches to corporate and nonprofit organizations.

Megan C. Kendall, MS, is a graduate from Purdue University who focused in media, technology, and society. Her research focuses on social media communication and crisis communication in a digital age. Professionally, she helps organizations navigate and communicate with social media.

\section{ORCID}

Katharine E. Miller (1) https://orcid.org/0ooo-0003-0851-0403

Megan C. Kendall (D) https://orcid.org/oooo-0oo1-6577-2579

\section{Note}

1. See https://cran.r-project.org/web/packages/twitteR/twitteR.pdf

\section{References}

Aaroe, L. (2011). Investigating frame strength: The case of episodic and thematic frames. Political Communication, 28, 207-226. https://doi.org/10.108o /10584609.2011.568041

An, S. K., \& Gower, K. K. (2009). How do the news media frame crises? A content analysis of crisis news coverage. Public Relations Review, 35, 107-112. https://doi.org/10.1016/j.pubrev.2009.01.010

Bennett, L. W. (2003). Communicating global activism. Information, Communication, and Society, 6, 143-168. https://doi.org/10.1080/13691180320 ooo93860a

Boyd, D., \& Crawford, K. (2012). Critical questions for big data. Information, Communication, and Society, 15, 662-679. https://doi.org/10.108o/136911 8X.2012.678878 
Carson, B. (2017, February 2). Over 200,000 people deleted Uber after the company operated service at JFK Airport during the Trump strike. Business Insider. Retrieved from http://www.businessinsider.com/over-2000oo-people -deleted-uber-after-deleteuber-2017-2? $r=U S \& I R=T \& I R=T$

Castells, M. (2012). Networks of outrage and hope: Social movements in the Internet age. Cambridge, England: Polity Press.

Chae, B. (2015). Insights from hashtag \#supplychain and Twitter analytics: Considering Twitter and Twitter data for supply chain practice and research. International Journal of Production Economic, 165, 247-259. https:// doi.org/10.1016/j.ijpe.2014.12.037

Coombs, W. T., \& Holladay, S. J. (2004). Communication and attributions in a crisis: An experimental study in crisis communication. Journal of Public Relations Research, 8, 279-295. https://doi.org/10.1207/s1532754xjprro804_04

de Vreese, C. H., Peter, J., \& Semetko, H. A. (2001). Framing politics at the launch of the euro: A cross-national comparative study of frames in the news. Political Communication, 18, 107-122. https://doi.org/10.1080 $/ 105846001750322934$

Doorley, J., \& Garcia, H. F. (2015). Reputation management: The key to successful public relations and corporate communication (3rd ed.). New York, NY: Routledge.

Earl, J., \& Kimport, K. (2011). Digitally enabled social change: Activism in the Internet age. Cambridge, MA: MIT Press.

Feldner, S. B., \& Berg, K. T. (in press). Blurring the lines between personal and organizational identity: The role of identity construction on Twitter when leaders change organizations. In S. Duhe (Ed.), Public relations and new media (3rd ed.). New York, NY: Peter Lang.

Giglietto, F., \& Selva, D. (2014). Second screen and participation: A content analysis on a full season of dataset of tweets. Journal of Communication, 64, 260-277. https://doi.org/10.1111/jcom.12085

Gioia, D., Schultz, M., \& Corley, G. K. (2000). Organizational identity, image, and adaptive instability. Academy of Management Review, 25, 63-81. Retrieved from http://www.jstor.org/stable/259263

Grandy, G., \& Mavin, S. (2011). Occupational image, organizational image and identity in dirty work: Intersections of organizational efforts and media accounts. Organization, 19, 765-786. https://doi.org/10.1177/1350508411422582

Gross, K. (2008). Framing persuasive appeals: Episodic and thematic framing, 
emotional response, and public policy. Political Psychology, 29, 169-192. https://doi.org/10.1111/j.1467-9221.2008.00622.x

Hallahan, K. (1999). Seven model of frame: Implications of public relations. Public Relations Research, 11, 205-242. https://doi.org/10.1207/s1532754x jprr1103_02

Heath, R. L., \& Palenchar, M. J. (2009). Strategic issue management: Organizations and public policy changes (2nd ed.). Thousand Oaks, CA: Sage.

Humphreys, L., Gill, P., Krishnamurthy, B., \& Newbury, E. (2013). Historicizing new media: A content analysis of Twitter. Journal of Communication, 63, 413-431. https://doi.org/10.1111/jcom.12030

Isaac, M. (2017, January 31). What you need to know \#DeleteUber. New York Times. Retrieved from https://www.nytimes.com/2017/o1/31/business /delete-uber.html?_r=o

Iyengar, S. (1990). Framing responsibility for political issues: The case of poverty. Political Behavior, 12, 19-40. https://doi.org/10.1007/BFoo992330 Iyengar, S. (1991). Is anyone responsible? How television frames political issues. Chicago, IL: University of Chicago Press.

Kim, M., Heo, Y. C., Choi, S. C., \& Park, H. W. (2014). Comparative trends in global communication networks of \#Kpop tweets. Quality and Quantity, 48, 2687-2702. https://doi.org/10.1007/s11135-013-9918-1

Krippendorff, K. (2013). Content analysis: An introduction to its methodology (3rd ed.). Thousand Oaks, CA: Sage.

Lutz, A. (2017, January 29). Furious customers are deleting the Uber app after drivers went to JFK Airport during a protest and strike. Business Insider. Retrieved from http://www.businessinsider.com/delete-uber-hashtag-jfk -airport-taxi-strikes-2017-1

Meraz, S., \& Papacharissi, Z. (2013). Networked gatekeeping and networked framing on \#Egypt. International Journal of Press/Politics, 18, 138-166. https://doi.org/10.1177/1940161212474472

Molyneux, L., Holton, A., \& Lewis, S. C. (2017). How journalists engage in branding on Twitter: Individual, organizational, and institutional levels. Information, Communication, and Society, 21, 1-16. https://doi.org/10.1080 /1369118X.2017.1314532

Muralidharan, S., Rasmussen, L., Patterson, D., \& Shin, J. H. (2011). Hope for Haiti: An analysis of Facebook and Twitter usage during the earthquake relief efforts. Public Relations Review, 37, 175-177. https://doi.org/10.1016 /j.pubrev.2011.01.010 
Powell, F. (2015, September). Quitting social media. NZ Business + Management, 29(8), M6.

Semetko, H. A., \& Valkenberg, P. M. (2000). Framing European politics: A content analysis of press and television news. Journal of Communication, 50(20), 93-109. https://doi.org/10.1111/j.1460-2466.200o.tbo2843.x

Siddiqui, F. (2017, January 29). Uber triggers protest for collecting fares during taxi strike against refugee ban. Washington Post. Retrieved from https:// www.washingtonpost.com/news/dr-gridlock/wp/2017/o1/29/uber-trig gers-protest-for-not-supporting-taxi-strike-against-refugee-ban/?utm _term $=.9 \mathrm{~b}_{2} \mathrm{~d}_{34} 4 \mathrm{f} 6 \mathrm{bfc} 7$

Smith, M. F. (2005). Activism. In R. Heath (Ed.), Encyclopedia of public relations (pp. 5-9). Thousand Oaks, CA: Sage.

Theocharis, Y., Lowe, W., van Deth, J. W., \& Garcia-Albacete, G. (2015). Using Twitter to mobilize protest action: Online mobilization patterns and action repertoires in the Occupy Wall Street, Indignados, and Aganaktismenoi movements. Information, Communication, and Society, 18, 202-220. https:// doi.org/10.1080/1369118X.2014.948035

Tucker, J. A., Metzger, M., Penfold-Brown, D., Bonneau, R., Jost, J., \& Nagler, J. (2015). Protest in the age of social media. Retrieved from https://medium .com/carnegie-corporation-international-peace-and/protest-in-the-age -of-social-media-7aegfd94obo6\#.6w3hv23mu

Twitter. (n.d.). About. Retrieved from https://about.twitter.com/company

Twitter Developer. (n.d.). Twitter developer documentation. Retrieved from https://dev.twitter.com/streaming/overview

Uber. (2018). Uber country and language list. Retrieved from http://www .uber.com/

Van de Donk, W., Loader, B., Nixon, P. G., \& Rucht, D. (2004). Cyberprotest: New media, citizens and social movements. London, England: Routledge. Wang, Y., Callan, J., \& Zheng, B. (2015). Should we use the sample? Analyzing datasets sampled from Twitter's stream API. ACM Transactions on the Web, 9. https://doi.org/10.1145/2746366

Wendling, M. (2017, January 30). Why are Trump opponents deleting their Uber accounts? Retrieved from http://www.bbc.com/news/blogs-trending $-38798158$ 